Bull. Chem. Soc. Ethiop. 2012, 26(3), 319-328.

Printed in Ethiopia

ISSN 1011-3924

DOI: http://dx.doi.org/10.4314/bcse.v26i3.1

(C) 2012 Chemical Society of Ethiopia

\title{
SIMPLE AND RAPID SPECTROPHOTOMETRIC ASSAY OF LEVOCETIRIZINE IN PHARMACEUTICALS THROUGH CHARGE-TRANSFER COMPLEXATION USING CHLORANILIC ACID AND 2,3-DICHLORO-5,6-DICYANOQUINONE AS $\pi$-ACCEPTORS
}

\author{
K. Basavaiah", M.S. Raghu and K.B. Vinay \\ Department of Studies in Chemistry, Manasagangothri, University of Mysore, Mysore 570 006, \\ India
}

(Received October 13, 2011; revised July 17, 2012)

\begin{abstract}
Simple, rapid, selective and fairly sensitive method is described for the determination of levocetirizine (LCTZ) in pure form and in its dosage forms. The method is based on the formation of intensely colored charge-transfer (CT) complexes between LCTZ as donor with two $\pi$ acceptors, chloranilic acid (CAA) and 2,3-dichloro-5,6-dicyanoquinone (DDQ) in acetonitrile-dioxane medium. The colored products were measured at $520 \mathrm{~nm}$ (CAA) and $590 \mathrm{~nm}$ (DDQ). Optimization of experimentation conditions is described. Beer's law is obeyed over the concentration ranges 3-120 and 2-80 $\mu \mathrm{g} \mathrm{mL}^{-1}$ for CAA and DDQ reagents, respectively, with corresponding molar absorptivity values of $4.0 \times 10^{3}$ and $5.5 \times 10^{3} \mathrm{~L} \mathrm{~mol} \mathrm{~cm}^{-1}$. The limits of quantification (LOQ) are 2.99 and $1.69 \mu \mathrm{g} \mathrm{mL}^{-1}$ for above reagents, respectively. Other method validation parameters, such as accuracy, precision, robustness and ruggedness, and selectivity are also reported. The composition of CT complex was found to be 1:1. The proposed method was successfully applied to the determination of the active ingredient in commercial tablets; and the results were in good agreement with those obtained by the official method.
\end{abstract}

KEY WORDS: Levocetirizine, Spectrophotometry, Charge-transfer complex, Pharmaceuticals

\section{INTRODUCTION}

Several drugs currently used are mixtures of enantiomers (recemates). In many cases, the two racemic enantiomers differ in their pharmacokinetic and pharmacodynamic properties. Of the two enantiomers, one is effective and even may exert side effects on the body [1]. Replacing existing recemates with single isomers has resulted in improved safety and/or efficacy profile of various recemates [2, 3]. Levocetirizine (LCTZ) [4-6], as the active enantiomer of cetirizine dihydrochloride, (2-[4-[(R)-(4-Chlorophenyl)phenylmethyl]-1-piperazinyl]ethoxy]-acetic acid dihydrochloride,) is a third generation non-sedative antihistamine [7]. It has the advantages of higher efficacy, less side effects, and longer duration over other antihistamines, and has begun to replace cetirizine in clinical therapy stepwise. It has been chemically proved that half dosage form of LCTZ (2.5 mg) has comparable antihistaminic activity to normal amount $(5.0 \mathrm{mg})$ of cetirizine in the treatment of allergic rhinitis and chronic idiopathic urticaria [8].

LCTZ is official in Indian Pharmacopoeia [9] and European Pharmacopoeia [10] which describes acid-base titration with $0.1 \mathrm{M} \mathrm{NaOH}$ in acetone: water medium. Literature survey revealed that LCTZ has been determined in plasma by liquid chromatography-tandem mass spectrometry [11] and in human serum by reverse-phase high performance liquid chromatography (RP-HPLC) along with other $\mathrm{H}_{1}$-receptor antagonists [12]. A study on the interaction of LCTZ with human serum albumin by molecular spectroscopy has recently been reported by Xiangping et al. [13].

Determination of small amounts of LCTZ in pharmaceutical preparations is important for medical and pharmaceutical needs, and hence it is crucial to develop simple, selective and cost-

*Corresponding author. E-mail: basavaiahk@yahoo.co.in 
effective methods for its determination as a part of compliance of specifications study: specimen quantity, sample homogenity, bio-decomposability and content uniformity in tablets.

LCTZ in combination with a number of other drugs in tablet dosage form has been assayed by UV-spectrophotometry $[14,15]$, ratio derivative spectrophotometry [16], TLC-densitometry [17] and RP-HPLC [18-21]. However, there are only three reports dealing with the determination of LCTZ when present alone in its dosage forms. An UV-spectrophotometric method [22] to determine effective content (LCTZ) in its tablets has been reported by Jing et al. The drug and related substance in solid oral formulation were assayed by HPLC [23]. The same technique has been applied for the stability-indicating method for the drug in bulk form and in dosage forms [24] and for the determination of LCTZ configuration stability in tablets using the chiral mode [25].

However, many of the reported methods for LCTZ in single-dosage form, particularly, the chromatographic methods [23-25] are complex; require expensive instrumental set up and skilled operator which are not always found in laboratories of developing and under developed countries. In sharp contrast, visible spectrophotometry, because of its inherent simplicity, fair selectivity and sensitivity, reasonable accuracy and precision and affordable instrumental set up, is still being used in both pharmaceutical quality control and clinical laboratories. Despite these advantages, the technique has not been used for the assay of LCTZ either bulk drug or in its dosage form.

In this work, a spectrophotometric method has been proposed for the determination of LCTZ in pharmaceuticals. The method involves a charge-transfer complex (CTC) formation reaction of the drug with two $\pi$-acceptors chloranilic acid (CAA) and 2,3-dichloro-5,6dicyanoquinone(DDQ) in acetonitrile-dioxane medium to form intensely colored radical anions measurable at $520 \mathrm{~nm}$ (CAA) and $590 \mathrm{~nm}$ (DDQ). The proposed method is determined to be simple and rapid employing low cost reagents and instrument.

\section{EXPERIMENTAL}

All absorption measurements were made using a Systronics model 106 digital spectrophotometer (Systronics Ltd, Ahmedabad, India) with $1 \mathrm{~cm}$ path length matched quartz cells.

Pharmaceutical grade LCTZ (certified to be $99.85 \%$ pure) was procured from Jubiliant Life Sciences Limited. Mysore, India and used as received. Allercet $5 \mathrm{mg}$ (Micro labs Ltd. Bangalore.) and xyzal $5 \mathrm{mg}$ (UCB India Pvt. Ltd. Mumbai.) tablets and lezyncet syrup (Mepro pharmaceuticals Pvt. Ltd. Surendranagar.) were purchased from local market. Acetonitrile and 1,4-dioxane (spectroscopic grade) were purchased from Merck, Mumbai, India. Distilled water was used wherever required. CAA of $0.1 \% \mathrm{w} / \mathrm{v}$ and DDQ of $0.2 \% \mathrm{w} / \mathrm{v}$ (both from S.D. Fine Chem Ltd, Mumbai) solutions were prepared freshly in 1,4-dioxane. Accurately weighed $4 \mathrm{~g}$ of the pure $\mathrm{NaOH}$ (Merck, India) was dissolved in water; the solution was made up to $100 \mathrm{~mL}$ with water.

\section{Standard drug solution in free base form (LVCT)}

Into a $125 \mathrm{~mL}$ separating funnel, an accurately weighed $24.0 \mathrm{mg}$ of pure LCTZ was transferred and dissolved in about $30 \mathrm{~mL}$ of water and the solution rendered alkaline by adding $5 \mathrm{~mL}$ of 1 $\mathrm{M} \mathrm{NaOH}$ and the content was shaken for $5 \mathrm{~min}$. The free base (LVCT) formed was extracted with three $20.0 \mathrm{~mL}$ portions of chloroform, the extract was passed over anhydrous sodium sulphate and collected in a $100 \mathrm{~mL}$ volumetric flask. The volume was made up to mark with acetonitrile and the resulting solution $\left(200 \mu \mathrm{g} \mathrm{mL}^{-1} \mathrm{LVCT}\right)$ was further diluted with acetonitrile 
to get a working concentration of $150 \mu \mathrm{g} \mathrm{mL}^{-1} \mathrm{LVCT}$ for CAA reagent and $100 \mu \mathrm{g} \mathrm{mL}^{-1} \mathrm{LVCT}$ for DDQ reagent.

\section{Construction of calibration curves}

CAA procedure. Varying aliquots of standard basic LCTZ solution equivalent to $3.0-120 \mu \mathrm{g}$ $\mathrm{mL}^{-1}\left(0.1-4.0 \mathrm{~mL}\right.$ of $\left.150 \mu \mathrm{g} \mathrm{mL}^{-1}\right)$ were accurately transferred into a series of $5 \mathrm{~mL}$ calibrated flasks and the total volume in each flask was brought to $4 \mathrm{~mL}$ by adding acetonitrile. After the addition of $1 \mathrm{~mL}$ of $0.1 \%$ CAA solution, the content was mixed well and the absorbance was measured at $520 \mathrm{~nm}$ against a reagent blank similarly prepared without adding LCTZ.

$D D Q$ procedure. Into a series of $5 \mathrm{~mL}$ calibration flasks, different aliquots $(0.1-4.0 \mathrm{~mL})$ of standard $100 \mu \mathrm{g} \mathrm{mL}^{-1} \mathrm{LCTZ}$ solution equivalent to $2-80 \mu \mathrm{g} \mathrm{mL}^{-1}$ basic LCTZ were accurately transferred, and to each flask $1 \mathrm{~mL}$ of $0.2 \%$ DDQ solution was added and mixed. After 5 minutes, the absorbance of the red coloured C-T complex was measured at $590 \mathrm{~nm}$ against the reference blank similarly prepared.

Calibration curves were prepared by plotting the absorbance versus LVCT concentrations, and the concentration of the unknown was read from the calibration curve or computed from the respective regression equation derived using the absorbance-concentration data.

\section{Procedure for commercial dosage forms}

Twenty tablets were weighed and pulverized. The amount of tablet powder equivalent to 24.0 mg of LCTZ was transferred into a $100 \mathrm{~mL}$ volumetric flask containing $30 \mathrm{~mL}$ of water. The content was shaken well for $20 \mathrm{~min}$. The resulting solution was filtered through Whatmann No. 42 filter paper and the filtrate was collected in to a $125 \mathrm{~mL}$ separating funnel. The salt was converted to free base as described earlier, LVCT solutions of concentrations 150 and $100 \mu \mathrm{g}$ $\mathrm{mL}^{-1}$ for CAA procedure and DDQ procedure, respectively, were prepared as described under the general procedure for pure drug and a suitable aliquot was used for assay by applying procedures described earlier.

The content of five syrup bottles ( $5 \mathrm{~mL}$ lezyncet syrup equivalent to $2.5 \mathrm{mg}$ levocetirizine dihydrochloride) were pooled and mixed together. Sixty $\mathrm{mL}$ of lezyncet syrup equivalent to 30.0 $\mathrm{mg}$ of levocetirizine dihydrochloride was accurately measured and transferred into a $125 \mathrm{~mL}$ separating funnel. Levocetirizine base was prepared by following the procedure described earlier. The resulting solution (300 $\mu \mathrm{g} \mathrm{mL}^{-1} \mathrm{LVCT}$ ) was diluted to 150 and $100 \mu \mathrm{g} \mathrm{mL}^{-1}$ and used for assay in CAA method and DDQ method, respectively.

\section{Procedure for the analysis of placebo blank and synthetic mixture}

A placebo blank containing starch $(40 \mathrm{mg})$, acacia $(35 \mathrm{mg})$, sodium citrate (35 mg), hydroxyl cellulose $(35 \mathrm{mg})$, magnesium stearate $(35 \mathrm{mg})$, talc $(40 \mathrm{mg})$ and sodium alginate $(35 \mathrm{mg})$ was prepared by mixing all the components into a homogeneous mixture. A $10 \mathrm{mg}$ of the placebo blank was accurately weighed and its solution was prepared as described under 'tablets', and then subjected to analysis by following the general procedures.

An accurately weighed $24.0 \mathrm{mg}$ of LCTZ was added to $200 \mathrm{mg}$ of placebo blank and homogenized. An amount of synthetic mixture equivalent containing $12.0 \mathrm{mg}$ LCTZ was accurately weighed and transferred into a $50 \mathrm{~mL}$ volumetric flask and the extract equivalent to $150 \mu \mathrm{g} \mathrm{mL}^{-1}$ LVCT was prepared as described under the general procedure for tablets and used in CAA method. Required volume of the above extract was diluted to $100 \mu \mathrm{g} \mathrm{mL}^{-1}$ with acetonitrile and used for DDQ procedure by following the general recommended procedure. 


\section{RESULTS AND DISCUSSION}

\section{Spectral characteristics and reaction mechanism}

The chemistry involved in the proposed method is the reaction of the basic nitrogen of levocetirizine base (LVCT) as n-donor with the $\pi$-acceptors (A), namely, CAA and DDQ to form charge transfer complexes. The formed charge transfer complexes are characterized by electronic transition(s) to an excited state in which there is a partial transfer of electronic charge from the donor to the acceptor moiety. As a result, the excitation energy of this resonance occurs very frequently in the visible region of the electro-magnetic spectrum [26]. This produces the usually intense colours characteristic for these complexes.

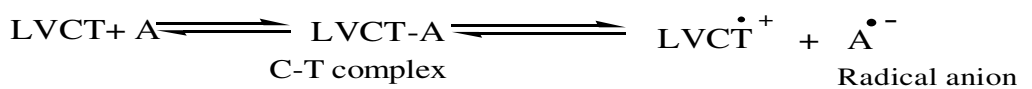

Therefore, LVCT, a nitrogenous base acting as n-donor was made to react with CAA and DDQ ( $\pi$-acceptors) to produce a coloured charge transfer complexes in dioxane-acetonitrile solvent system. The reaction of CAA as a $\pi$-acceptor with levocetirizine base as n-electron donor results in the formation of an intense orange-red product which exhibits absorption maxima at $520 \mathrm{~nm}$ (Figure 2a) due to the formation of the corresponding CAA radical anion. DDQ also acts as a $\pi$-acceptor and the LVCT-DDQ charge transfer complex resulted in the formation of an intense reddish violet color which exhibit three maxima at 590, 545 and $460 \mathrm{~nm}$ ( Figure 2b) [27].

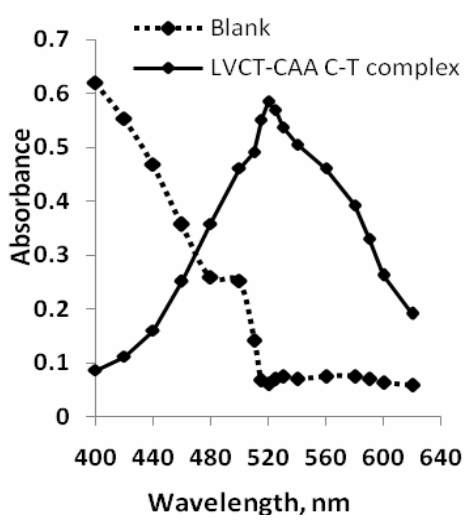

(a)

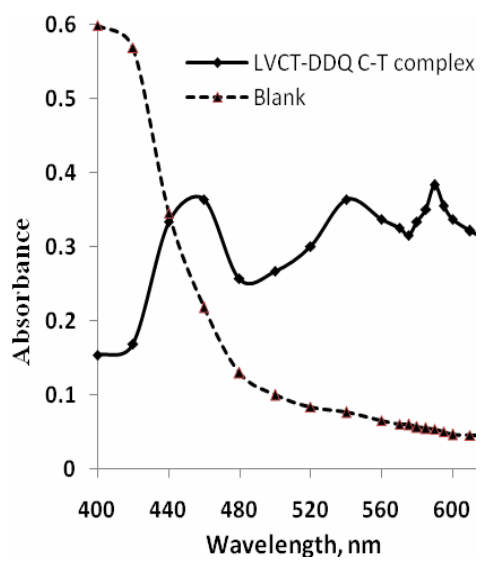

(b)

Figure 1. Absorption spectra of: (a) LVCT-CAA (60.0 $\left.\mu \mathrm{g} \mathrm{mL}^{-1} \mathrm{LCTZ}\right)$ and (b) LVCT-DDQ (30 $\mu \mathrm{g} \mathrm{mL}^{-1}$ LCTZ) C-T complexes.

These bands can be attributed to the formation of DDQ radical anions arising from the complete transfer of n-electrons from donor to acceptor moieties in acetonitrile [28]. The absorption band at $590 \mathrm{~nm}$ was selected as analytical wavelength keeping in view the sensitivity of the reaction product and blank absorbance. The dissociation of the complex is promoted by the high ionizing power of the acetonitrile [29]. The hydrochloride salts of amines do not react with $\pi$-acceptors due to non-availability of non-bonding electrons (n-electrons) on the nitrogen atom. To determine amine-HCI, it is necessary to first neutralize the hydrochloride and then extract the 
amine into a non-aqueous solvent [30]. The neutralization of the amine hydrochloride with sodium hydroxide and extraction of $\mathrm{HCl}$-free-amine into chloroform followed by evaporating the chloroform was described by Mostafa et al. [31]. Since levocetirizine dihydrochloride as such did not react with the $\pi$-acceptors, the salt was converted to base followed by extraction, evaporation and dissolving the residue in acetonitrile. The possible reaction scheme is given in Scheme 1.
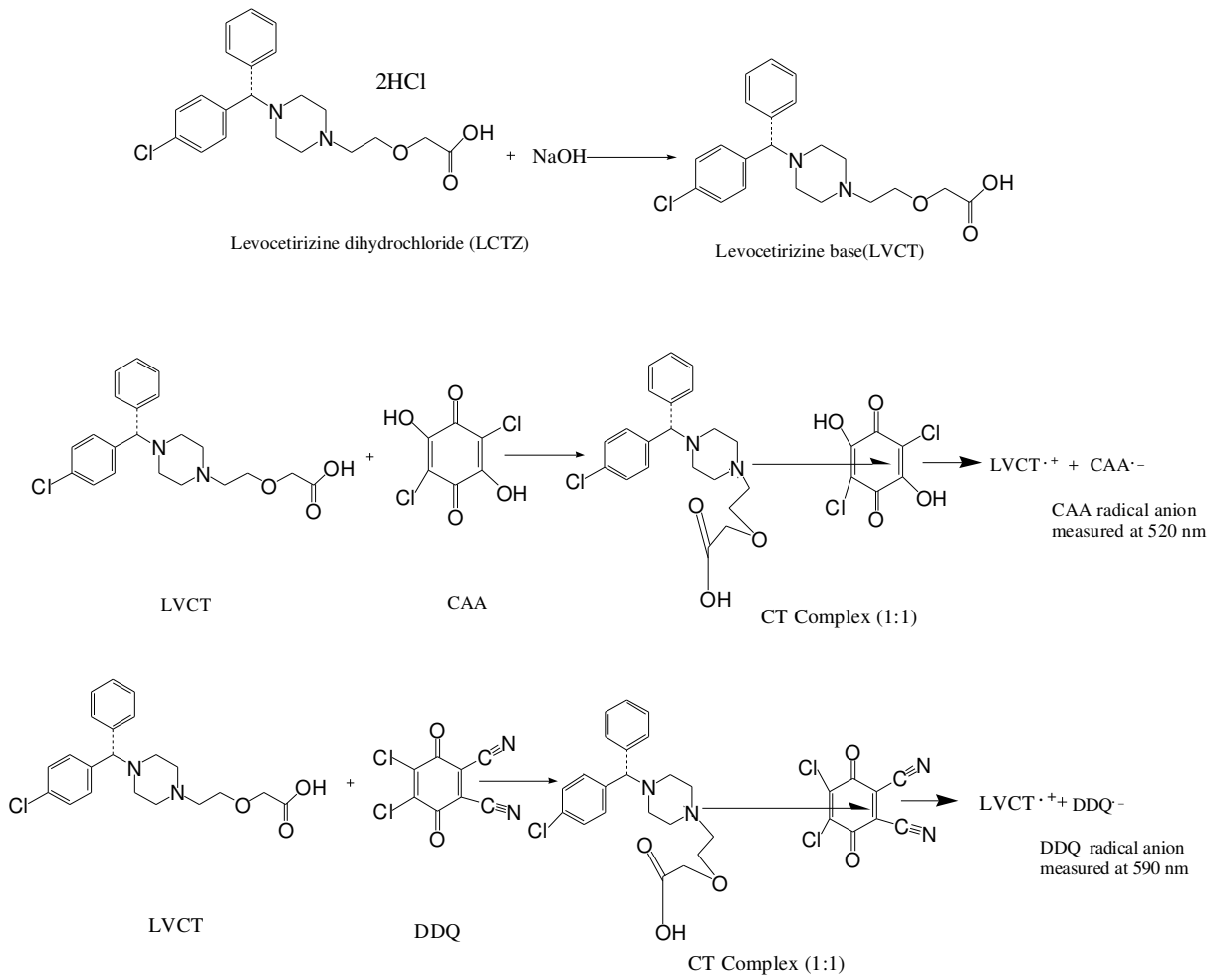

Scheme 1. Possible reaction pathway for the formation of C-T complex between LVCT and CAA/DDQ in acetonitrile-1,4-dioxane medium.

Optimization of experimental variables

Effect of reagent concentration. The effect of the reagent concentration on the intensity of the color developed at the selected wavelengths was ascertained by adding different amounts of the reagents CAA and DDQ to fixed concentrations of 60.0 and $40.0 \mu \mathrm{g} \mathrm{mL}^{-1} \mathrm{LCTZ}$ in using CAA and DDQ reagents, respectively. It was found that $1.0 \mathrm{~mL}$ each of $0.1 \%$ CAA and $0.2 \%$ DDQ solutions was sufficient for the formation of maximum and reproducible color intensity and the highest absorbance remained unaffected by further addition of these reagents, this can be seen from Figure 2.

Effect of solvent. In order to select the suitable solvent for charge transfer complex formation, the reaction of LVCT with CAA and DDQ was carried out in different solvents. The acetonitriledioxane medium was found to be opt in the case of CAA because CAA in 1,4-dioxane exists in unionized form and acts as a $\pi$-acceptor like quinones [32] and the acetonitrile showed super 
priority over many solvents used such as chloroform, 2-propanol, dichloroethane, methanol and ethanol. Acetonitrile was found to be an ideal solvent in the case of DDQ, because it afforded the maximum sensitivity when compared with other solvents.

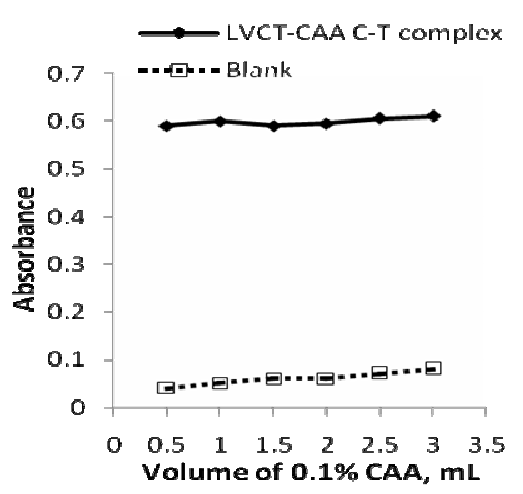

(a)

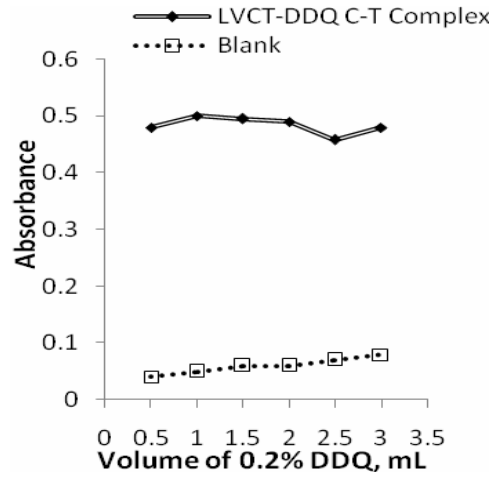

(b)

Figure 2. Effect of reagent (a) CAA Method $\left(60.0 \mu \mathrm{g} \mathrm{mL}^{-1} \mathrm{LCTZ}\right)$ and (b) DDQ Method (40.0 $\left.\mu \mathrm{g} \mathrm{mL}^{-1} \mathrm{LCTZ}\right)$.

Effect of reaction time. The optimum reaction time was determined by following the color development upon the addition of reagent solution to the LVCT solution at room temperature. Complete color development was attained after $5 \mathrm{~min}$ in both procedures. The absorbance of these radical anions remained stable for at least 60 and 45 min for CAA method and DDQ method, respectively.

Composition of the C-T complexes. The composition of the C-T complexes with either CAA or DDQ was evaluated by following the Job's continuous variations method [33]. The experiments were performed by preparing and mixing equimolar solutions of drug and reagent (CAA reagent: $5.4 \times 10^{-4} \mathrm{M}$ LCTZ and CAA; DDQ reagent: $2.16 \times 10^{-4} \mathrm{M}$ ) by maintaining the total volume at $5.0 \mathrm{~mL}$. The plots of mole ratios versus the absorbance values were measured, and the results revealed that the formation of C-T complex between drug and reagent followed a 1:1 reaction stoichiometry. This finding was anticipated by the presence of one basic electron donating center (nitrogen atom) in the LCTZ structure. Based on this fact, the reaction pathway for the formation of C-T complex is proposed and shown in Scheme 1.

\section{Method Validation}

Linearity, sensitivity, limits of detection and quantification. A linear correlation was found between absorbance at $\lambda_{\max }$ and concentration of LVCT in the ranges given in Table 1. Regression analysis of the Beer's law data using the method of least squares was made to evaluate the slope (b), intercept (a), standard deviations of y-axis, slope and intercept, and correlation coefficient (r) for each system and the values are presented in Table 1. The optical characteristics such as Beer's law limits, molar absorptivity and Sandell sensitivity values of the method are also given in Table 1. The limits of detection (LOD) and quantitation (LOQ) calculated according to ICH guidelines [34] using the formulae: $\mathrm{LOD}=3.3 \mathrm{~S} / \mathrm{b}$ and LOQ $=10$ $\mathrm{S} / \mathrm{b}$, (where $\mathrm{S}$ is the standard deviation of blank absorbance values, and $\mathrm{b}$ is the slope of the calibration plot) are also presented in Table 1. The moderate values of $\varepsilon$ and Sandell sensitivity and LOD indicate the sensitivity of the proposed methods. 
Table 1. Sensitivity and regression parameters.

\begin{tabular}{|l|l|l|}
\hline Parameter & CAA reagent & DDQ reagent \\
\hline$\lambda_{\max }, \mathrm{nm}$ & 520 & 590 \\
\hline Color stability, min & 60 & 45 \\
\hline Linear range, $\mu \mathrm{g} \mathrm{mL}^{-1}$ & $3-120$ & $2-80$ \\
\hline Molar absorptivity $(\varepsilon), \mathrm{L} \mathrm{mol}^{-1} \mathrm{~cm}^{-1}$ & $4.0 \times 10^{3}$ & $5.5 \times 10^{3}$ \\
\hline Sandell sensitivity, $\mu \mathrm{g} \mathrm{cm}^{-2}$ & 0.1147 & 0.0808 \\
\hline Limit of detection $(\mathrm{LOD}), \mu \mathrm{g} \mathrm{mL}{ }^{-1}$ & 0.99 & 0.56 \\
\hline Limit of quantification $(\mathrm{LOQ}), \mu \mathrm{g} \mathrm{mL}^{-1}$ & 2.99 & 1.69 \\
\hline Regression equation, $\mathrm{Y}^{* * *}$ & \multicolumn{2}{|l|}{} \\
\hline Intercept (a) & 0.0021 & 0.0085 \\
\hline Slope (b) & 0.0093 & 0.0126 \\
\hline Regression coefficient $(\mathrm{r})$ & 0.9988 & 0.9993 \\
\hline Standard deviation of intercept $(\mathrm{Sa})$ & 0.0344 & 0.0004 \\
\hline Standard deviation of slope $(\mathrm{Sb})$ & 0.1125 & 0.0031 \\
\hline
\end{tabular}

Limit of determination as the weight in $\mu \mathrm{g} \mathrm{mL}^{-1}$ of solution, which corresponds to an absorbance of $\mathrm{A}=$ 0.001 in a cuvette of cross-sectional area $1 \mathrm{~cm}^{2}$ and $1=1 \mathrm{~cm} .{ }^{* *} \mathrm{Y}=\mathrm{a}+\mathrm{bX}$, where $\mathrm{Y}$ is the absorbance, $\mathrm{X}$ is concentration in $\mu \mathrm{g} \mathrm{mL}^{-1}$, a is intercept, $\mathrm{b}$ is slope, $\pm \mathrm{tS}_{\mathrm{a}} / \sqrt{\mathrm{n}}=$ confidence limit for intercept, $\pm \mathrm{tS}_{\mathrm{b}} / \sqrt{\mathrm{n}}_{\mathrm{n}}=$ confidence limit for slope.

Precision and accuracy. The assays described under "general procedures" were repeated seven times within the day to determine the repeatability (intra-day precision) and five times on different days to determine the intermediate precision (inter-day precision) of the methods. These assays were performed for three levels of analyte. The results of this study are summarized in Table 2 . The percentage relative standard deviation (\%RSD) values were $\leq 1.9$ $\%$ (intra-day) and $\leq 2.3 \%$ (inter-day) indicating high precision of the method. Accuracy was evaluated as percentage relative error (RE) between the measured mean concentrations and taken concentrations for QTP. Bias $\{$ bias $\%=[$ (Concentration found - known concentration $) \mathrm{x}$ $100 /$ known concentration]\} was calculated at each concentration and these results are also presented in Table 2. Percent relative error (\%RE) values of $\leq 2.3 \%$ demonstrates the high accuracy of the proposed methods.

Table 2. Evaluation of intra-day and inter-day accuracy and precision.

\begin{tabular}{|c|c|c|c|c|c|c|c|}
\hline \multirow[b]{2}{*}{ Reagent } & \multirow[b]{2}{*}{$\begin{array}{l}\text { LVCT taken, } \\
\mu \mathrm{g} \mathrm{mL}^{-1}\end{array}$} & \multicolumn{3}{|c|}{ Intra-day $(\mathrm{n}=7)$} & \multicolumn{3}{|c|}{ Inter-day $(\mathrm{n}=5)$} \\
\hline & & $\begin{array}{l}\text { LVCT found, } \\
\mu \mathrm{g} \mathrm{mL}^{-1}\end{array}$ & $\% \mathrm{RE}$ & $\%$ RSD & $\begin{array}{l}\text { LVCT found, } \\
\mu \mathrm{g} \mathrm{mL}^{-1}\end{array}$ & $\% \mathrm{RE}$ & $\%$ RSD \\
\hline CAA & $\begin{array}{l}30 \\
60 \\
90\end{array}$ & $\begin{array}{l}29.6 \\
61.3 \\
89.5\end{array}$ & $\begin{array}{l}1.3 \\
2.2 \\
0.5\end{array}$ & $\begin{array}{l}1.5 \\
0.5 \\
1.8\end{array}$ & $\begin{array}{l}30.5 \\
60.8 \\
91.3\end{array}$ & $\begin{array}{l}1.7 \\
1.4 \\
1.5\end{array}$ & $\begin{array}{l}2.4 \\
1.7 \\
2.2\end{array}$ \\
\hline DDQ & $\begin{array}{l}20 \\
40 \\
60\end{array}$ & $\begin{array}{l}19.5 \\
40.7 \\
59.4\end{array}$ & $\begin{array}{l}2.4 \\
1.9 \\
0.9\end{array}$ & $\begin{array}{l}1.9 \\
1.5 \\
1.3\end{array}$ & $\begin{array}{l}20.4 \\
40.5 \\
60.9\end{array}$ & $\begin{array}{l}2.3 \\
1.3 \\
1.5\end{array}$ & $\begin{array}{l}2.3 \\
1.6 \\
1.3\end{array}$ \\
\hline
\end{tabular}

$\%$ RE: percent relative error, \% RSD: relative standard deviation, $\mathrm{n}=$ number of measurements.

Selectivity. The results obtained from placebo blank and synthetic mixture analyses revealed that the inactive ingredients used in the tablet preparation did not interfere in the assay of active ingredient. The absorbance values obtained from the placebo blank solution were almost equal to the absorbance of the blank which revealed no interference from the adjuvants. To study the role of additives added to the synthetic sample, $3 \mathrm{~mL}$ of the resulting solution prepared by using 
synthetic mixture (150 and $100 \mu \mathrm{g} \mathrm{mL}^{-1}$ in LVCT from CAA and DDQ reagents) was assayed (n $=5$ ). The percentage recoveries of $97.2-102.8 \%$ with $\%$ RSD values in the range 0.9-2.3 demonstrated the accuracy as well as the precision of the proposed method and complement the findings of the placebo blank analysis with respect to selectivity.

Robustness and ruggedness. The robustness of the method was evaluated by making small incremental changes in the volume of reagent and contact time, and the effect of the changes was studied on the absorbance of the complex systems. The changes had negligible influence on the results as revealed by small intermediate precision values expressed as \% RSD $(\leq 1.8 \%)$. Method ruggedness was demonstrated having the analysis done by four analysts, and also by a single analyst performing analysis on four different instruments in the same laboratory. Intermediate precision values (\%RSD) in both instances were in the range $0.8-4.4 \%$ indicating acceptable ruggedness. The results are presented in Table 3.

Table 3. Method robustness and ruggedness expressed as intermediate precision (\% RSD).

\begin{tabular}{|c|c|c|c|c|c|}
\hline \multirow{3}{*}{ Method } & \multirow{3}{*}{$\begin{array}{l}\text { LVCT } \\
\text { taken, } \\
\mu \mathrm{g} \mathrm{mL}^{-1}\end{array}$} & \multicolumn{2}{|l|}{ Robustness } & \multicolumn{2}{|l|}{ Ruggedness } \\
\hline & & Parameters a & & \multirow[b]{2}{*}{$\begin{array}{l}\text { Inter-analysts } \\
(\% \text { RSD }),(n=4)\end{array}$} & \multirow[b]{2}{*}{$\begin{array}{l}\text { Inter-instruments } \\
(\% \text { RSD }),(n=4)\end{array}$} \\
\hline & & $\begin{array}{l}\text { Volume of } \\
\text { CAA/DDQ }\end{array}$ & $\begin{array}{l}\text { Reaction } \\
\text { time }^{\Psi}\end{array}$ & & \\
\hline \multirow{3}{*}{ CAA } & 30 & 1.8 & 1.5 & 0.8 & 2.7 \\
\hline & 60 & 1.4 & 1.9 & 1.1 & 3.4 \\
\hline & 90 & 1.0 & 2.3 & 0.7 & 2.5 \\
\hline \multirow{3}{*}{ DDQ } & 20 & 1.1 & 2.2 & 1.3 & 3.1 \\
\hline & 40 & 1.6 & 2.1 & 1.0 & 4.4 \\
\hline & 60 & 1.8 & 1.9 & 1.4 & 3.6 \\
\hline
\end{tabular}

*The volumes of CAA or DDQ added were $1 \pm 0.2 .{ }^{\Psi}$ The reaction times were $5 \pm 1 \mathrm{~min}$.

Application. The proposed methods were applied for the quantification of LCTZ in its dosage forms. The results obtained were compared with the reference method [10], which involves acid-base titration to the potentiometric end point in acetone: water system. Statistical analysis of the results did not detect any significant difference in the performance of the proposed method to the reference method with respect to accuracy and precision as revealed by the Student's t-value and variance ratio F-value [35]. The results of this study are given in Table 4.

Table 4. Results of analysis of tablets by the proposed methods and statistical comparison of the results with the reference method.

\begin{tabular}{|c|c|c|c|c|}
\hline \multirow{2}{*}{$\begin{array}{l}\text { Tablet brand } \\
\text { name }\end{array}$} & \multirow{2}{*}{$\begin{array}{l}\text { Nominal } \\
\text { amount } \\
\#\end{array}$} & \multicolumn{3}{|c|}{ Found $^{*}$ (percent of label claim $\pm \mathrm{SD}$ ) } \\
\hline & & $\begin{array}{l}\text { Reference } \\
\text { method [10] }\end{array}$ & CAA reagent & $\begin{array}{l}\text { DDQ } \\
\text { reagent }\end{array}$ \\
\hline${ }^{\mathrm{a}}$ Allercet-5 & 5 & $100.3 \pm 0.64$ & $\begin{array}{l}101.7 \pm 1.2 \\
\mathrm{t}=2.34, \mathrm{~F}=3.34\end{array}$ & $\begin{array}{l}102.4 \pm 1.4 \\
\mathrm{t}=2.58, \mathrm{~F}=5.20\end{array}$ \\
\hline${ }^{\mathrm{b}}$ Xyzal-5 & 5 & $99.38 \pm 0.56$ & $\begin{array}{l}98.48 \pm 0.9 \\
\mathrm{t}=1.67, \mathrm{~F}=2.52\end{array}$ & $\begin{array}{l}98.68 \pm 0.9 \\
t=1.56, F=2.52\end{array}$ \\
\hline $\begin{array}{l}{ }^{\mathrm{c}} \text { Lezyncet } \\
\text { (Syrup) }\end{array}$ & 2.5 & $97.28 \pm 0.72$ & $\begin{array}{l}97.84 \pm 1.24 \\
t=0.71, F=2.96\end{array}$ & $\begin{array}{l}98.20 \pm 1.6 \\
t=2.05, F=4.69\end{array}$ \\
\hline
\end{tabular}

${ }^{*}$ Mean value of 5 determinations. \# mg/tablet in tablets and $\mathrm{mg} / 5 \mathrm{~mL}$ in Syrup. Tabulated t-value at the $95 \%$ confidence level and for four degrees of freedom is 2.77 . Tabulated F-value at the $95 \%$ confidence level and for four degrees of freedom is 6.39. ${ }^{\psi}$ Marketed by: ${ }^{\mathrm{a}}$ Micro labs Ltd, ${ }^{\mathrm{b}} \mathrm{UCB}$ India Pvt. Ltd. ${ }^{\mathrm{c}}$ Mepro pharmaceuticals Pvt. Ltd. 
Recovery study. To further assess the accuracy of the proposed methods, recovery experiment was performed by applying the standard-addition technique. The recovery was assessed by determining the agreement between the measured standard concentration and added known concentration to the sample. The test was done by spiking the pre-analysed tablet powder and syrup solution with pure LVCT at three different levels (50, 100 and $150 \%$ of the content present in the tablet powder (taken) and the total was found by the proposed method. Each test was repeated three times. From this test the percentage recovery values were found in the range of $98.0-103.1 \%$ with standard deviation values from 0.8 $3.5 \%$. Closeness of the results to $100 \%$ showed the fairly good accuracy of the method. These results are shown in Table 5.

Table 5. Results of recovery study via standard-addition method.

\begin{tabular}{|c|c|c|c|c|c|c|c|c|}
\hline \multirow[b]{2}{*}{$\begin{array}{l}\text { Tablets/syrup } \\
\text { studied }\end{array}$} & \multicolumn{4}{|c|}{ CAA reagent } & \multicolumn{4}{|c|}{ DDQ reagent } \\
\hline & \begin{tabular}{|l} 
LVCT \\
in tablet, \\
$\mu \mathrm{g} \mathrm{mL}^{-1}$
\end{tabular} & $\begin{array}{l}\text { Pure LVCT } \\
\text { added, } \quad \mu \mathrm{g} \\
\mathrm{mL}^{-1}\end{array}$ & $\begin{array}{l}\text { Total } \\
\text { found, } \\
\mu g \mathrm{~mL}^{-1}\end{array}$ & $\begin{array}{l}\text { Pure LVCT } \\
\text { recovered } \\
\left(\text { percent } \pm \mathrm{SD}^{*}\right)\end{array}$ & \begin{tabular}{|l} 
LVCT \\
in tablet, \\
$\mu \mathrm{g} \mathrm{mL}^{-1}$
\end{tabular} & $\begin{array}{l}\text { Pure LVCT } \\
\text { added, } \quad \mu \mathrm{g} \\
\mathrm{mL}^{-1}\end{array}$ & $\begin{array}{l}\text { Total } \\
\text { found, } \\
\mu \mathrm{g} \mathrm{mL} \mathrm{m}^{-1}\end{array}$ & $\begin{array}{l}\text { Pure LVCT } \\
\text { recovered } \\
\text { (percent } \pm \mathrm{SD}^{*} \text { ) }\end{array}$ \\
\hline Allercet-5 & $\begin{array}{l}30.04 \\
30.04 \\
30.04\end{array}$ & $\begin{array}{l}15.0 \\
30.0 \\
45.0\end{array}$ & $\begin{array}{l}45.41 \\
60.51 \\
74.16\end{array}$ & $\begin{array}{l}102.4 \pm 3.3 \\
101.6 \pm 1.4 \\
98.0 \pm 1.5\end{array}$ & $\begin{array}{l}20.06 \\
20.06 \\
20.06\end{array}$ & $\begin{array}{l}10.0 \\
20.0 \\
30.0\end{array}$ & $\begin{array}{l}30.14 \\
40.78 \\
49.88\end{array}$ & $\begin{array}{c}100.8 \pm 0.8 \\
103.6 \pm 2.6 \\
99.4 \pm 1.0\end{array}$ \\
\hline $\begin{array}{l}\text { Lezyncet } \\
\text { syrup }\end{array}$ & $\begin{array}{l}29.94 \\
29.94 \\
29.94\end{array}$ & $\begin{array}{l}15.0 \\
30.0 \\
45.0\end{array}$ & $\begin{array}{l}45.24 \\
60.57 \\
76.28\end{array}$ & $\begin{array}{l}102.0 \pm 1.7 \\
102.1 \pm 3.0 \\
102.9 \pm 2.4\end{array}$ & \begin{tabular}{|l|}
19.92 \\
19.92 \\
19.92
\end{tabular} & $\begin{array}{l}10.0 \\
20.0 \\
30.0\end{array}$ & $\begin{array}{l}30.19 \\
40.71 \\
51.00\end{array}$ & $\begin{array}{l}102.7 \pm 1.7 \\
103.9 \pm 3.5 \\
103.6 \pm 2.9\end{array}$ \\
\hline
\end{tabular}

"Mean value of three determinations.

\section{CONCLUSIONS}

This is the first report on the application of visible spectrophotometry for the quantification of levocetirizine dihydrochloride in pharmaceuticals. The methods are based on well-characterized charge-transfer complexation reaction, and have the advantages of simplicity, speed, accuracy and precision, and use of inexpensive equipment compared to the reported HPLC methods. The DDQ reagent is more sensitive than the CAA reagent as seen from the higher molar absorptivity. The statistical parameters and the recovery data reveal good accuracy and precision of the method. The method can be used as general method for the determination of LCTZ in bulk powder, tablets and syrup solution. The methods have many advantages over the separation techniques such as HPLC and include reduced cost, and speed with high accuracy. Thus, the methods are useful for the quality control and routine analysis of LCTZ in pharmaceuticals since there is no interference from the common excipients that might be found in commercial formulations.

\section{ACKNOWLEDGEMENTS}

Authors thank Jubiliant Life Sciences Limited, Mysore, India, for gifting pure levocetirizine. Authors are grateful to the authorities of the University of Mysore, Mysore, for permission and facilities.

\section{REFERENCES}

1. Imran, A.; Vinod, G.; Hassan, A.; Prashanth, S.; Bhavtosh, S. Chirality 2007, 19, 453.

2. Patil, P.A.; Kothekar, M.A. Indian J. Med. Sci. 2006, 60, 427.

3. Bernard, T.; William, F.T. Chirality 1990, 2, 129

4. Tillement, B.T.; Bree, F. Biochem. Pharmacol. 2003, 66, 1123.

5. F. Estelle, R. Simons, J. Keith, Simons. J. Allergy Clin. Immunol. 2005, 116, 355. 
6. Deruaz, C.; Leimgruber, A.; Berney, M.; Pradevand, E.; Spertini, F. J. Allergy Clin. Immunol. 2004, 113, 669.

7. Neil, J.O. The Merck Index, 13th ed., Merck Research Laboratories, Merck and Co. Inc., Maryndale, White House Station, New Jersey, USA; 2001; p 2030.

8. Devalia, J.L.; De Vos, C.; Hanotte, F.; Baltes, E. Allergy 2001, 56, 50.

9. Indian Pharmacopoeia, Vol. II, The controller of Publications, Ministry of Health and Family Welfare: Govt. of India, New Delhi; 2007; p 1290.

10. European Pharmacopoeia, 6.0, Vol. II, EDQM, Council of Europe: Stranbourg, France; 2008; p 1479.

11. Gunasakaran, S.; Rao, N.; Arunkumar, R.; Olaganathan, A. Biomirror 2010, 1, 1.

12. Saeed, A.M.; Sultana, N.; Agha, Z.M.; Farhan, A.S. J. Chromatogr. Sci. 2010, 48, 382.

13. Xiangping, L.; Yingxiang, D.; Wen, S.; Junping, K.; Boyang, Y. Spectrochim. Acta A. 2009, $741,1189$.

14. Lakshmana Prabhu, S.; Shirwaikar, A.; Dinesh Kumar, C.; Aravind Kumar, G. Indian. J. Pharm. Sci. 2008, 70, 236.

15. Merukar, S.S.; Mhaskar, P.S.; Bavaskar, S.R.; Burade, K.B.; Dhabale P.N. J. Pharm. Sci. Res. 2009, 1, 38.

16. Choudhari, V.; Kale, A.; Abnawe, S.; Kuchekar, B.; Gawli, V.; Patil, N. Int. J. Pharmtech. Res. 2010, $2,4$.

17. Sharma, S.; Sharma, M.C.; Kohli, D.V.; Sharma, A.D.; Der Pharmacia Lettre 2010, 2, 489.

18. Ashokkumar, S.; Senthil Raja, M.; Perumal, P. Int. J. Pharm. Res. 2009, $1,8$.

19. Ambadas, R.R.; Vaishali, S.N. Lat. Am. J. Pharm. 2010, 29, 1020.

20. Kamarapu, S.K.; Vaijayanthi Bahlul, Z.; Venisetty, R.K. Int. J. Pharm. Sci Nanotech. 2010, 1,3 .

21. Shaikh, K.A.; Patil. A.T. Int. J. ChemTech Res. 2010, 2, 454.

22. Jing, L.; Jun, Y.; Fei-yan, H. J. Huaihua University 2006, 8.

23. Yadav, B.; Yadav, S. J. Pharm. Res. 2010, 3, 2817.

24. Dhaneshwar, S.R.; Bhutale, N.K.; Mhaske, D.V; Kadam, S.S. J. pharm. Pharmacol. 2006, $58,10$.

25. Hommoss, R.; Elzein, H.; Haidar, S. Int. J. Pharm. Pharm. Sci. 2011, 3, 103.

26. Fekria, M.; Attia, A. IL Farmaco 2000, 55, 659.

27. Abdel-Hamid, M.E.; Abuirjeie, M.A. Talanta 1988, 35, 242.

28. Basavaiah, K.; Abdulrahman, S.A.M. Thai J. Pharm. Sci. 2010, 34, 134.

29. Rahman, N.; Nasrul Hoda, M. J. Pharm. Biomed. Anal. 2003, 31, 381.

30. Walash, M.; Sharaf-Ei-Din, M.; Metwalli, M.E.S.; RedaShabana M. Arch. Pharm. Res. 2004, 27, 720 .

31. Mostafa, A.A.; Bebawy, L.I.; Refaat, H.H. J. Pharm. Biomed. Anal. 2002, 27, 889.

32. Nafisur, R.; Mohammad, K. J. Anal. Chem. 2005, 60, 636.

33. Rose, J. Advanced Physico-Chemical Experiments, Pitman: London; 1964.

34. International Conference on Hormonisation of Technical Requirements for Registration of Pharmaceuticals for Human Use, ICH Harmonised Tripartite Guideline, Validation of Analytical Procedures: Text and Methodology Q2(R 1), Complementary Guideline on Methodology dated 06 November 1996, incorporated in November 2005, London.

35. Inczedy, J.; Lengyel, T.; Ure, A.M.; IUPAC Compendium of Analytical Nomenclature: Definitive Rules, Blackwell Science Inc.: Boston; 1998. 